WŁODZISŁAW ZEIDLER ${ }^{1}$

Hohenwestedt

Studia Psychologica

UKSW

16(1) 2016 s. $121-138$

\title{
FRANCISZKI BAUMGARTEN EMPIRYCZNE BADANIE KŁAMSTWA U DZIECI I MŁODZIEŻY
}

\author{
... koniecznem jest bliżej rozpatrzeć \\ ten tak bezkrytycznie przez pedagogów przyjęty postulat, \\ ze kłamstwo jest występkiem \\ F. Baumgarten (1927, s. 109)
}

\section{STRESZCZENIE}

Na przełomie wieków XIX i XX rozwój psychologii ograniczały w sposób ewidentny zarówno bariery polityczne, jak i wpływy ideologiczne. Pozytywnie wspomagały jej rozwój, prowadzone przez nią samą, badania empiryczne. Było to szczególnie ważne ze względu na rozwijanie w każdym z nowo powstałych krajów własnej terminologii psychologicznej. Badania i publikacje Franciszki Baumgarten, o których będzie mowa w tym artykule, wykonane w języku polskim w roku 1914, a opublikowane w tymże języku dopiero po 13 latach pokazują jeden z bardziej interesujących i szczególnie wartościowy przykład rozwoju metodologii badań empirycznych oraz są dowodem intensywnego rozwoju i specjalizacji języka polskiej psychologii.

Słowa kluczowe: kwestionariusz w badaniach empirycznych, różnice indywidualne, kłamstwo w domu i szkole, przyczyny czy motywy kłamstwa, kłamstwo czy solidarność

FRANCES BAUMgARTEN'S EMPIRICAL RESEARCH OF LIE (FALSEHOOD) IN CHILDREN AND TEENAGERS

\section{ABSTRACT}

At the turn of $19^{\text {th }}$ and $20^{\text {th }}$ century Frances Baumgarten's empirical research was one of the positive influences in the development of psychology, otherwise clearly hampered by political barriers and ideological influences. It was particularly important for the development of psychological terminology in each of the emerging new countries. Frances Baumgarten's research, which was done in 1914 and published in several publications in Polish 13 years later, shows one of the more interesting and particularly valuable examples of the development of empirical research methodology and is the evidence of high development and specialization of Polish psychological language.

Keywords: questionnaire in empirical research, individual differences, lie in school and home, reasons or motives of lie, lie or solidarity

$1 \quad$ Adres do korespondencji: wlzeidler@gmail.com. 


\section{WPROWADZENIE}

Wypowiedzi na temat stanu polskiej psychologii zarówno podczas trwania, jak i już po zakończeniu I wojny światowej muszą być ryzykowne z dwóch różnych względów. Z jednej strony istniało zróżnicowanie poziomów rozwoju polskiej kultury oraz nauki pod różnymi zaborami, stosownie do nasilenia ucisku. $\mathrm{Z}$ drugiej strony należy wziąć pod uwagę i to, że na przełomie wieków XIX i XX sama psychologia znalazła się $\mathrm{w}$ fazie intensywnego rozwoju, zarówno ze względu na sposób definiowania przedmiotu swoich zainteresowań oraz na metodologię, jak i na stosunek do innych nauk, a także coraz to inne, stale rosnące zapotrzebowanie społeczne - ciągle jeszcze po obydwu stronach Oceanu (por. Roback, 1952) odmienne, ale coraz bardziej zróżnicowane i „niecierpliwe”. W tym obszarze interesującym i dobitnym przykładem może być znany spór między „,filozofami” oraz „psychologami” o obsadzanie katedr psychologii (por. Ash, 1995, s. 42-50). Jest rzeczą oczywistą, że obydwa czynniki (te w stosunku do psychologii zewnętrzne, jak i wewnętrzne) pozostawały we wzajemnej coraz to innej interakcji, co stanowiło wówczas podstawę dla powstania nowych orientacji, kierunków i szkół, a następnie okazję dla odmiennych interpretacji wyników badań empirycznych. Wśród nich z kolei za szczególnie szkodliwe i bałamutne uznać należy te, które nie były w stanie oddzielić od siebie, w tamtym okresie szczególnie ważnych, ale wyraźnie odmiennych, płaszczyzn: nauki, ideologii i polityki. Wreszcie dobrze znane, coraz to nowsze historyczne zawieruchy spowodowały wiele różnych kłopotów i trudności w zakresie gromadzenia oraz możliwości korzystania z materiałów źródłowych. Zniszczonych, zagubionych, zapomnianych lub po prostu „trudno dostępnych”, jak np. list Wilhelma Wundta (1916) na temat przyszłości Polski po zakończeniu I wojny światowej (por. Zeidler, 2008). Nie trzeba dowodzić, że do tych celowo „zapomnianych” należały w okresie panowania w Polsce komunizmu także prace Franciszki Baumgarten. W tym opracowaniu chcę przedstawić jedną z nich, szczególnie oryginalną oraz interesującą, ważną zarówno dla psychologii polskiej, jak i europejskiej: Kłamstwo dzieci i młodzieży (Na podstawie ankiety w szkołach łódzkich) (Warszawa, 1927). Ważną, owszem, zarówno ze względu na swoją treść oraz metodę, jak i dzieje jako programu badań i jako publikacji. Te trzy okoliczności zadecydowały także o sposobie prezentowania tej publikacji. Tak więc przedmiotem mojego szczegółowego zainteresowania nie będą ani elementy biografistyki, ani rekonstrukcja myśli psychologicznej, ale sama publikacja, traktowana jako wytwór, albo produkt psychologiczny w takim rozumieniu, jakie wprowadził do psychologii Karl Bühler ${ }^{2}$. Ten zabieg metodologiczny nie

2 Przypomnę, co na ten temat napisałem już w innym miejscu (Zeidler, 2011a, s. 33). Rozpocznę od cytowanej tam wypowiedzi Charlotte Bühler (1962, s. 37): „Niezapomnianą zasługą Karla Bühlera pozostanie to, że wskazał i uzasadnił zasadność i konieczność trzech różnych sposobów postępowania metodycznego". Postępowanie to było zależne od tego, czy psycholog 
jest sprzeczny z tym, że praca Franciszki Baumgarten na temat kłamstwa dzieci i młodzieży stanowi element, ale przede wszystkim dokument historii psychologii: zarówno polskiej, jak i europejskiej, przez niektórych historyków psychologii niesłusznie ignorowany.

Poszczególni autorzy zapisują historię w rozmaity sposób. Jedni starają się opisać możliwie dokładnie przebieg wydarzeń, inni koncentrują się na analizie wewnętrznych przeżyć tych „aktorów”, którzy ich szczególnie interesują, a jeszcze inni przedstawiają opisy i analizy konkretnych wytworów poszczególnych jednostek, całego narodu albo pokolenia. Tym, co ich interesuje najbardziej, jest zrozumienie sensu opisanych wydarzeń, albo - w ujęciu bardziej nowoczesnym: ich interpretacja ${ }^{3}$. Każda $\mathrm{z}$ tych orientacji ma swoje zalety i wady, także gdy idzie o historię psychologii (por. Zeidler, 2003). Wydaje się jednak, że ta ostatnia (tzn. interpretacja), chociaż w odniesieniu do historii psychologii dotychczas „nie była nadużywana”, może być szczególnie przydatna. Spojrzenie na konkretne dzieła konkretnych psychologów, z uwzględnieniem czasu i miejsca ich powstania, może otwierać perspektywę szczególnie pouczającą, która ukazuje w nowym świetle znane już, albo też właśnie te zapomniane, „fakty” i dokumenty.

\section{CO BĘDZIE TUTAJ OBIEKTEM NASZEGo ZAINTERESOWANIA}

Poniżej zamierzam przedstawić jedną z prac Franciszki Baumgarten, która nie należy do szerzej i dobrze znanego nurtu jej zainteresowań, a chociaż po części wręcz zapomniana albo „wyparta”, jest dokumentem niezwykle ważnym, jeżeli idzie o zrozumienie specyfiki rozwoju całej polskiej psychologii w okresie wiodącym ku niepodległości. Jej szczególną zaletą jest to, że w swoisty i bardzo interesujący sposób ukazuje ona miejsce i znaczenie ówczesnej polskiej psychologii w złożonym nurcie rozwijającej się właśnie wtedy psychologii europejskiej. Mam na myśli książkę Kłamstwo dzieci i młodzieży, opublikowaną w języku polskim w roku 1927 nakładem Naszej Księgarni. Historia powstania tej książki jest bardzo skomplikowana i zostanie omówiona dokładniej w dalszej części tego opracowania. Zakładam, że biografia jej Autorki jest w Polsce wystarczająco dokładnie znana, dlatego nie będę się nią tutaj zajmował szczegółowo. Dla zainteresowanego Czytelnika dobrym wprowadzeniem może być publikacja Ryszarda Stachowskiego (1992) na temat sylwetki Franciszki Baumgarten-Tramer. Obszerniejszy opis jej postaci oraz naukowych osiągnięć i zasług znajdziemy w artykule Edelgard Daub (2015) zamieszczonym w pracy

zajmował się: (1) wewnętrznymi przeżyciami (Erlebnisse), (2) zewnętrznym zachowaniem (Verhalten) czy (3) trwałymi wytworami (Produkte).

3 Pamiętać należy, że każdej interpretacji towarzyszy niebezpieczeństwo deformacji sensu interpretowanych wydarzeń. Miewamy wówczas do czynienia $\mathrm{z}$ instrumentalizacją interpretacji, czyli podporządkowaniem jej uprzednio przyjętym poglądom. 
zbiorowej pod naukową redakcją Sibylle Volkmann-Raue i Helmuta E. Lücka: Najwybitniejsze kobiety w psychologii XX wieku. Ale już wcześniej, bo w roku 1996, ta sama Autorka poświęciła jej osobną i obszerną monografię, wydaną we Frankfurcie nad Menem jako 12. tom serii dotyczącej historii psychologii, wydawanej pod redakcją H.E. Lücka ${ }^{4}$. W kilku innych publikacjach (np. Rudmin, 2006; Giger, 2010; Richebächer, 2010) znajdujemy cenne materiały dotyczące wybranych nurtów dodatkowych zainteresowań Franciszki Baumgarten (Giger: dzieci wybitnie uzdolnione, Rudmin i Richebächer: pacyfizm).

To właśnie różnorodność nurtów twórczości Franciszki Baumgarten (a potem także Franziski Baumgarten-Tramer ${ }^{5}$ ) stała się przyczyną zainteresowania jej losami życiowymi oraz rozmaitością dokonań oraz dzieł ze strony wielu psychologów i pedagogów o różnej orientacji teoretycznej i odmiennych preferencjach naukowych. Okazję ku temu oraz obiektywną podstawę stanowiły szerokie zainteresowania naukowe Franciszki Baumgarten oraz bardzo długa lista jej publikacji i osiągnięć naukowych. Wspomniana wyżej Edelgard Daub (1996, s. 134-142) przedstawiła listę 42 publikacji zwartych (książki i broszury) autorstwa lub współautorstwa Franciszki Baumgarten. Większość z nich (ale nie wszystkie) powstała pierwotnie w języku niemieckim, część $\mathrm{z}$ nich była tłumaczona na języki francuski, włoski, hiszpański, portugalski, szwedzki, duński, norweski, rosyjski i oczywiście także polski, chyba że oryginał został zapisany w języku polskim - tak jak to było w przypadku tej publikacji, którą zajmiemy się tutaj dokładniej. Ta, o której będzie mowa poniżej, była jedną z wcześniejszych prac Franciszki Baumgarten i podobnie jak kilka innych spośród wczesnych prac, została wykonana oraz napisana $\mathrm{w}$ oryginale $\mathrm{w}$ języku polskim jeszcze w okresie trwania zaborów! Jej książki były często oraz pochlebnie recenzowane. Lista artykułów jest o wiele dłuższa (patrz: Daub, 1996).

Aby lepiej zrozumieć podłoże naukowych zainteresowań oraz inspiracji Franciszki Baumgarten, należy zwrócić uwagę na przebieg oraz okoliczności zdobywania przez nią wykształcenia akademickiego. Rozpoczyna je immatrykulacja w Uniwersytecie Jagiellońskim w Krakowie jesienią 1905 roku. Właśnie jakby w cieniu tych wszystkich rewolucyjnych wydarzeń, które miały miejsce także w Królestwie Polskim w pierwszej połowie roku 1905, Franciszka, żywo zainteresowana problemami społecznymi, jest przekonana, że filozofia pomoże je wszystkie rozwiązać (por. Daub, 1996, s. 24), dlatego decyduje się na studiowanie

\footnotetext{
Więcej w: Zeidler, 2012.

5 Od roku 1924 Baumgarten zamieszkiwała w Solothurn w Szwajcarii, gdzie poślubiła Moritza Tramera (1882-1963), jednego z twórców psychiatrii dziecięcej, który także wspomagał pionierskie działania Heinricha Hanselmanna (1885-1960) na rzecz rozwoju ortopedagogiki i pedagogiki specjalnej. Na liście jej długiej i bogatej twórczości znajdują się prace powstałe w tym samym czasie, ale sygnowane albo nazwiskiem Baumgarten, albo Baumgarten-Tramer. Kryteria tej sygnatury są niejasne.
} 
w UJ literatury i filozofii. Ale dlaczego w Krakowie? Wiadomo, że w UJ od roku 1867 (!) ponownie prowadzono wykłady w języku polskim. Z profesorów cieszących się największym uznaniem należy wymienić Hrabiego Stanisława Tarnowskiego (historyka literatury) oraz filozofa ks. Stefana Pawlickiego (1839-1916). Do rozpoczynających właśnie karierę naukową należał Władysław Heinrich (1869-1957) ${ }^{6}$. Wykształcenie zdobył w Monachium oraz Zurychu, gdzie pod kierunkiem Richarda Avenariusa napisał i obronił (w roku 1894) rozprawę doktorską pt. Bemerkungen zur neueren physiologischen Psychologie in Deutschland ${ }^{7}$. Po dwóch semestrach studiów w UJ, w roku 1906 Franciszka Baumgarten przeniosła się na studia w paryskiej Sorbonie, ale po dwóch semestrach, w roku 1907 wraca do Krakowa ${ }^{8}$. Teraz może już współpracować z Heinrichem $w$ jego Laboratorium do eksperymentalnych badań psychologicznych. Niestety, w tym czasie kobiety w Uniwersytecie Jagiellońskim nie mogą jeszcze się doktoryzować. Okoliczność ta stała się przyczyną przeniesienia do Zurychu, gdzie pod kierunkiem Gustawa W. Störinga ${ }^{9}$ przygotowała rozprawę doktorską pt. Die Erkenntnislehre von Maine de Biran. Eine Historische Studie, która ukazała się drukiem w Krakowie w roku 1911. Wydział Filozoficzny Uniwersytetu w Zurychu nadał Franciszce Baumgarten stopień doktora $\mathrm{z}$ datą 4 kwietnia 1911 roku i oceną magna cum laude.

Teraz zaczyna się dość długi okres poszukiwania własnej naukowej tożsamości. Proces ten, bardzo złożony, bywał przez biografów Franciszki Baumgarten, zainteresowanych głównie jej twórczością w zakresie psychotechniki, ignorowany albo analizowany jedynie powierzchownie. Tymczasem w rzeczywistości nurtowały ją problemy mające swoje korzenie w filozofii, etyce i nauce o społeczeństwie. Poszukiwanie własnej tożsamości naukowej trwało przez kilka następnych lat. W tym okresie miał miejsce także powrót do rodzinnego miasta

6 Edelgard Daub (1996, s. 27) jako datę urodzenia Władysława Heinricha podaje rok 1863. Autorzy polscy (np. Tatarkiewicz, 2001, s. 359; R. Stachowski, 2000, s. 259; W. Szewczuk, 1988, s. 7) podają rok 1869. Według danych podanych przez Rzepę i Dobroczyńskiego (2009, s. 103) w latach 1905-1906 Heinrich odbył dłuższe podróże do Wielkiej Brytanii i Stanów Zjednoczonych Ameryki Północnej.

7 Więcej w: Panczyk, Zeidler (2011, s. 249-250) i Rzepa, Dobroczyński (2009, s. 100-107). Dodać należy, że fragmenty tej pracy w nowszej redakcji zamieścili niemieccy autorzy: Helmut Hildebrandt, Eckart Scheerer w pracy z roku 1990 (!) zawierającej wybór prac Hugo Münsterberga z wczesnego okresu jego twórczości, a zatytułowanej Frühe Schriften zur Psychologie (Berlin: Springer-Verlag).

8 W. Szewczuk podaje, że Władysław Heinrich w roku akademickim 1905/1906 przebywał w USA (Heinrich, 1988, s. 9).

9 G.W. Störing (1860-1946) po ukończeniu studiów w zakresie filozofii i medycyny zdobył także doktorat w zakresie filozofii. Swoją współpracę z Wilhelmem Wundtem zakończył habilitacją w Lipsku. Podobnie jak jego trzej poprzednicy, został powołany na stanowisko profesora w Zurychu z polecenia Wundta. Jako lekarz zajmował się także psychopatologią i prowadził eksperymenty psychofizjologiczne (Maercker, 2007). 
i ponowne zetknięcie się z jego problemami. Od roku 1907, w Królestwie Polskim nauczanie w szkołach - jako zdobycz rewolucji 1905 roku, także w Łodzi - mogło się odbywać w języku ojczystym, tzn. polskim. Jednak tylko w szkołach prywatnych i pod nadzorem carskich urzędów. Wiadomo, że od roku 1907, powołane na mocy odpowiedniego „ukazu”, istnieje w Warszawie Polskie Towarzystwo Psychologiczne. A oprócz tego, także w Warszawie, od roku 1907 funkcjonuje, kierowane przez Anielę Szyc, Polskie Towarzystwo Badań nad Dziećmi. Baumgarten nawiązuje $\mathrm{z}$ tym Towarzystwem bliskie kontakty, unika jednak wiązania się w sposób formalny z jakąkolwiek instytucją. Zanim w roku 1914, w związku z wybuchem I wojny światowej, zdobędzie schronienie w Berlinie, zaraz po uzyskaniu doktoratu „próbuje” swoich sił w Królestwie Polskim.

Edelgard Daub (1996, s. 143) odnotowała sześć popularnych artykułów Baumgarten z lat 1911-1914, które ukazały się na łamach „Nowej Gazety”, w dodatku tygodniowym Nauka i Życie. Wiadomo też, że przy współpracy z Florianem Znanieckim jako redaktorem naukowym Baumgarten przetłumaczyła na język polski pracę Édouarda Claparède’a Psychologia dziecka i pedagogika eksperymentalna, która ukazała się w Warszawie w roku $1918^{10}$. Jak mogła wyglądać współpraca z Florianem Znanieckim, który - jak wiadomo w latach 1914-1918 przebywał w Chicago, pozostaje pytaniem otwartym (por. Rudmin, 2006, s. 2). Ten sam autor podaje informację o empirycznych badaniach Franciszki Baumgarten (Rudmin, 2006, s. 10) podczas I wojny światowej na temat związanych z nią przeżyć 700 polskich dzieci - wyniki tych badań zostały opublikowane w artykule: Baumgarten, F., Crescott, D.A. (1928). Why children hate: An experimental investigation of the reactions of school children in Poland to the enemy occupation. Journal of Educational Psychology, 19, 303-312.

Jeżeli idzie o tematykę publikacji Franciszki Baumgarten, to, przez szereg lat (od drugiego dziesięciolecia XX wieku poczynając - por. np. Zeidler, Lück, 2014) wiodącym tematem jej zainteresowań była psychotechnika. Obok niejzaraz po zakończeniu I wojny światowej, aż do wyjazdu do Szwajcarii - uwagę badaczki absorbowała także problematyka psychologii dziecka, szczególnie problemy dzieci wybitnie uzdolnionych (por. Rudmin, 2006; Giger, 2010). Ale to były tylko tematy wiodące. $\mathrm{W}$ połączeniu z problemami psychotechniki zajmowała się także zagadnieniami dotyczącymi stosunków międzyludzkich oraz problematyką osobowości i charakteru.

Tutaj chcę, jak już wspomniałem, przedstawić jedną z jej pierwszych publikacji, która powstała w języku polskim, a jednak oryginał został opublikowany dopiero po ukazaniu się drugiego wydania jego tłumaczenia na język niemiecki! Zaraz na wstępie należy podkreślić, że było to jedno z pierwszych psychologicznych badań empirycznych (rok 1912!), wykonanych na polskich dzieciach

10 Édouard Claparède: Psychologia dziecka i pedagogika eksperymentalna. Tłum. F. Baumgarten, red. F. Znaniecki. Warszawa, 1918, Wyd. Wende. 
w języku polskim, już w „,polskich” szkołach, chociaż jeszcze na terenie zaboru rosyjskiego ${ }^{11}$. Istnieją jednak jeszcze dwie inne osobliwości, które ukazują rangę oraz znaczenie pracy Franciszki Baumgarten. Okoliczności historyczne (zabór rosyjski) uniemożliwiły publikację pracy w języku polskim, w którym zostały przeprowadzone badania empiryczne. Wykonanie tych badań przed wybuchem wojny jest dowodem na wysoki poziom rozwoju polskiej psychologii już podczas trwania zaborów. Poziom i jakość wyników badań Franciszki Baumgarten, ocenionych przez Williama Sterna i Ottona Lipmanna, otworzył jej drogę najpierw do redagowanego przez nich, wysoko cenionego pisma ${ }^{12}$, a tym samym do „gmachu” bujnie rozwijającej się psychologii europejskiej. Osobliwością drugą była właśnie ta wysoka ocena Sterna i Lipmanna oraz to, że jej badania, także w przekładzie na język niemiecki (Baumgarten, 1917) ${ }^{13}$, zainteresowały czytelników trwale i na tyle, że po ośmiu latach koniecznym okazało się ponowne wydanie książki w języku niemieckim (1926). Wreszcie nadszedł czas na ponowne opublikowanie, ale tym razem już w języku polskim, jako języku oryginału (Baumgarten, 1927, s. 5): „Wydanie niniejsze jest zatem wydaniem oryginału pracy. Zawiera ono jednak dopisek i bibliografię według 2-go wydania niemieckiego. Autorka. Solura (Szwajcaria), 1927r.”

\section{UWOLNIĆ OD ZAPOMNIENIA: CEL I METODA PRACY}

Nie jestem pewien, czy wielu czytelnikom dobrze jest znana ciekawa praca Hanny Malewskiej i Heliodora Muszyńskiego (1962) Kłamstwo dzieci, czy budzi ona nadal tak duże zainteresowanie, jak to miało to miejsce przed 50 laty. Jestem natomiast pewien, że pracę Franciszki Baumgarten należy dzisiaj zaliczyć do nieznanych lub zapomnianych. Jest ona bowiem dzisiaj, w odróżnieniu od tej pierwszej, trudno dostępna. A poza tym autorzy tej pierwszej należeli przez wiele lat do autorów obowiązkowych lektur pedagogicznych. Również na pedagogów powoływała się Franciszka Baumgarten, pisząc zaraz na początku Przedmowy do polskiego wydania swojej pracy, że istnieje „zupełny brak systematycznej pracy o kłamstwie u dzieci w literaturze europejskiej”. Z tej racji, wychodząc naprzeciw potrzebom pedagogów niemieckich, zdecydowała się na wydanie swojej pracy w języku niemieckim w Lipsku, już w roku 1917. Ukazała

11 Celowym będzie tutaj wskazanie na to, że nie były to jeszcze badania eksperymentalne. Zatem ich znaczenie należy oceniać w kontekście odmienności metodologii badań empirycznych (Brentano) oraz badań eksperymentalnych (Wundt).

12 W latach 1908-1932 William Stern oraz Otto Lipmann byli wydawcami czasopisma „Zeitschrift für angewandte Psychologie und psychologische Sammelforschung”, w swoim czasie niezwykle ważnego i wysoko cenionego organu teoretycznego, dzisiaj nadal dokumentu historycznego o wyjątkowym znaczeniu.

13 Tekst pracy opublikowanej w języku niemieckim w roku 1917 obejmuje 111 stron, a tekst pracy w języku polskim - 139 stron. 
się ona jako jeden z książkowych dodatków do wysoko cenionego czasopisma „Zeitschrift für angewandte Psychologie...”, redagowanego przez Williama Sterna i Ottona Lipmanna.

Podobnie jak w innych pracach z przełomu wieków XIX i XX, przeprowadzenie ostrej, a przy tym jednoznacznej granicy między tym, co dotyczy jej celu oraz metody, nie jest rzeczą łatwą. W polskiej literaturze Ryszard Stachowski (2011) zwrócił uwagę na pojawiające się ciągle jeszcze trudności w odróżnieniu dwóch, raczej często stosowanych w psychologii metod: ankiety oraz kwestionariusza. Tenże Autor podaje, że znany i uważany za pierwszy kwestionariusz do badań psychologicznych, czyli tzw. Arkusz Danych Osobistych Woodwortha, został opracowany i był stosowany w końcowej fazie I wojny światowej w USA, a jego pierwsza publikacja ukazała się w roku 1919 (Woodworth, 1919). W tej samej pracy Stachowski podaje też, że już w roku 1886 polski psycholog i pedagog Jan Władysław Dawid (1859-1914) ${ }^{14}$ opublikował - najpierw w „Przeglądzie Pedagogicznym", a rok później w osobnym wydaniu książkowym (97 stron) Program postrzeżen psychologiczno-wychowawczych nad dzieckiem od urodzenia do 20 roku życia. Zamiarem Dawida było opracowanie narzędzia, które pomogłoby w gromadzeniu oraz porządkowaniu obserwacji dotyczących rozwoju dziecka. Jego intencją było przygotowanie narzędzia, które można stosować w badaniach longitudinalnych, także wówczas, kiedy interesuje nas rozwój jednostki. Wydaje się, że w tym właśnie punkcie należy upatrywać zalet jego pracy, mimo że oddzielenie jej fragmentów dotyczących celu (poznanie zaawansowania rozwoju) od metody bywa trudne. Zgodzimy się jednak, że Dawid chciał skonstruować narzędzie pomocne w poznawaniu jednostki, która teraz w zależności od wyników poznania - będzie poddawana już bardziej celowym, zindywidualizowanym oddziaływaniom pedagogicznym.

Trudno powiedzieć, gdzie miał początek ten najbardziej rozpowszechniony nurt rozwoju kwestionariuszy jako metody naukowej (por. Zeidler, 2011b, s. 8191). Z całą pewnością należy wymienić dwa ośrodki. Pierwszy znajdował się w Lipsku, gdzie w roku 1906 Krueger oraz Spearman opublikowali wyniki badań nad zastosowaniem rachunku korelacyjnego w badaniach psychologicznych. Niebawem Stern (1911) pokazał możliwości wykorzystania tej procedury w badaniach nad różnicami indywidualnymi. Franciszka Baumgarten (1927, s. 25) - właściwie już w roku 1912 - powoła się w stosownym miejscu na pracę Sterna z roku 1911 (s. 132), aby uzasadnić wybór metody badań własnych.

Drugi ośrodek, z Gerardem Heymansem jako głównym reprezentantem, miał swoją siedzibę w Groningen w Holandii. Heymans znał możliwości zastosowania rachunku korelacyjnego, ale jednocześnie starał się poddawać analizie obszerny materiał badawczy (por. np. Heymans, Wiersma, 1906; Heymans,

14 W zakresie metodyki badań psychologicznych i pedagogicznych Jan Władysław Dawid był uczniem Wilhelma Wundta oraz Hermanna Ebbinghausa. 
1910). W podstawowym wariancie metodyka polegała na zestawieniu celowo dobranych pytań, które w postaci listu zostały wysłane do nauczycieli i lekarzy. Teraz oni udzielali odpowiedzi na pytania $z$ arkusza, a następnie odsyłali wyniki do Uniwersytetu w Groningen. Tam dane podlegały analizie i opracowaniu. Materiał był obszerny, ale „analityk” nie miał żadnego kontaktu z „respondentem”. Była to zarówno w oczach Sterna, jak i Baumgarten niebezpieczna słabość metodyki badań Heymansa i Wiersmy.

Ten mankament Franciszka Baumgarten postanowiła ze swoich badań wyeliminować. Jej celem nie były bowiem diagnozy indywidualne, ale rozpoznanie specyfiki i nasilenia zjawiska nazywanego kłamstwem w określonej populacji. Podtytuł: na podstawie ankiety w szkołach łódzkich populację tę lokalizuje, ale jeszcze niezbyt dokładnie. $Z$ tej racji cel badań wymagał dodatkowego wyjaśnienia. $\mathrm{W}$ interesującym przeglądzie historycznym Baumgarten przypomina poglądy, które łączyły występowanie kłamstwa u dzieci z mętnie definiowaną „dziedzicznie złą naturą". Z biegiem czasu zauważono, że wymaga ona - tak, właśnie owa natura (sic!) - odpowiedniego wychowania. Dalsze obserwacje ujawniły i to, że dzieci żyją jakby w dwóch różnych światach. Obok tego rzeczywistego istnieje także świat fantazji. I być może cała historia rozwoju dziecka jest niczym innym, jak historią wędrówek pomiędzy tymi dwoma światami? Jednak „wraz z rozwojem zdolności uwagi i sądzenia, przewaga fantazji w psychice dziecka zanika, a z nią i kłamliwość" (Baumgarten, 1927, s. 15). Czy zatem kłamstwo w życiu ludzkim jest zjawiskiem charakterystycznym tylko dla dzieciństwa? Baumgarten (1927, s. tamże) powie, że „dorosły człowiek bawi się swą fantazją wtedy, gdy w młodym wieku fantazja bawi się dzieckiem”. Jeżeli zatem chcielibyśmy się zgodzić z przypuszczeniem, że kłamstwo jest swoistym błędem podczas wędrówki pomiędzy światami fantazji i rzeczywistości, to byłoby nam potrzebne opisanie owych błędów oraz ich konsekwencji. I tym właśnie tropem zdaje się podążać Franciszka Baumgarten. Jest rzeczą zrozumiałą, że na temat dziecięcych fantazji mamy w tym punkcie niewiele do powiedzenia. Wypada zatem rozpocząć od tego świata, który możemy nazwać rzeczywistym. Wszakże zaraz przy pierwszym spojrzeniu okazuje się, że dziecko musi funkcjonować w dwóch światach rzeczywistych. Ten pierwszy nazywamy domem, a drugi szkoła.

Tak czy inaczej, zaraz na wstępie istnieje potrzeba ustalenia częstotliwości zjawiska, które nazywamy kłamstwem. Oczywiście najlepiej zaraz z podziałem na te dwa odrębne „światy”. Częstość kłamstwa w domu i szkole stanowi rozdział wprowadzający w część szczegółową pracy Baumgarten. Spośród wszystkich 1078 kłamstw odnotowanych na podstawie ankiety, 505 przypadało na szkołę, a 573 na dom. Był to wynik oczywiście niezgodny z wypowiedzią jednego $\mathrm{z}$ ankietowanych chłopców w wieku 16 lat: „Ponieważ w szkole jestem 6 godzin, a w domu 18 godzin, stąd wniosek prosty, że w domu kłamię 3 razy więcej” (uczeń, kl. siódma)" (Baumgarten, 1927, s. 40). Ta rozbieżność 
wyników i deklaracji sugeruje działanie także innych czynników determinujących częstotliwość występowania kłamstwa. Czy były one w tym projekcie badań kontrolowane? Staną się one lepiej zrozumiałe po zapoznaniu się z metodą i metodyką prowadzenia badań empirycznych przez dr Franciszkę Baumgarten $\mathrm{w}$ rok po uzyskaniu doktoratu na podstawie rozprawy doktorskiej dotyczącej historii filozofii.

W tym miejscu należy wskazać na wyraźną dyscyplinę metodologiczną w omawianym projekcie badań. Po dyskusji na temat poglądów teoretycznych dotyczących obszaru przyszłych badań Baumgarten przeprowadziła celową i dokładną analizę przydatnych metod badania zjawiska kłamstwa. Jej wybór padł teraz na ankietę. Po rozważeniu możliwych trudności oraz braków tej metody Autorka zdecydowała się na przyjęcie tylko sześciu możliwie „szeroko otwartych" pytań, które nie powinny niczego sugerować ani ograniczać swobody wypowiedzi ankietowanych uczniów. Silnym punktem - nowością w stosunku do wcześniejszych, wspomnianych wyżej innych prac - był sposób przeprowadzania ankiety. Ankietę przeprowadzono w szkołach łódzkich. Odpowiedzi udzieliła 553-osobowa grupa dzieci i młodzieży (269 dziewczynek, 284 chłopców, w wieku od 9 do 18 lat). Pomysł oraz inicjatywa wykonania tego programu badań powstały w roku 1912 w łódzkim oddziale Towarzystwa Badań nad Dziećmi. Same badania zostały przeprowadzone osobiście przez Franciszkę Baumgarten w roku 1914. Początkowo w niektórych szkołach „przełożeni” nie chcieli się zgodzić na ich przeprowadzenie. W takich sytuacjach pomocną okazywała się rekomendacja Anieli Szycówny. Oto lista pytań w tym programie, opracowanych przez Franciszkę Baumgarten (1927, s. 27):

1) Czy skłamałeś (-aś) kiedy w domu?

2) Czy skłamałeś (-aś) kiedy w szkole?

3) Daj przykłady twego kłamstwa.

4) Czy wstydziłeś (-aś) się swego kłamstwa?

5) Czy żałowałeś (-aś), że skłamałeś?

6) Czy przypominasz sobie swe pierwsze kłamstwo $w \dot{z} y c i u$ ?

Pytania Autorka zadawała ankietowanym dzieciom ustnie, w grupach zbliżonych do zespołów klasowych. Ankietowani mieli tym samym możliwość wyjaśnienia wątpliwości i pozbycia się zahamowań wynikających z niezwykłości sytuacji. Odpowiedzi były udzielane na piśmie przy respektowaniu tempa pracy respondentów. Celem jej pracy albo - jak sama pisze - zadaniem, jakie sobie postawiła, było „zbadanie, jakie motywy powodują kłamstwo u dzieci i jaki jest stosunek dziecka do kłamstwa” (1927, s. 26).

\section{MoTyWy KŁAMSTWA}

Wśród przedstawionych wyżej pytań wyróżniają się dość wyraźnie dwie grupy. W grupie pierwszej pytania dotyczą lokalizacji samego kłamstwa 
i jego okoliczności. Kłamstwo zostaje odniesione do jednego z dwóch wyżej wskazanych „światów”: domu i szkoły. Autorka nawiązuje także do problemu aktualnego w ówczesnej literaturze psychologicznej - wieku, w którym w zachowaniach dzieci pojawia się kłamstwo. W materiale Autorki, spośród 553 ankietowanych dzieci tylko 193 było w stanie przypomnieć sobie swoje pierwsze kłamstwo oraz wiek, w którym do niego doszło - od 3 do 13 lat. Połowa z tych odpowiedzi wskazywała szósty rok życia.

\section{Kłamstwa w domu}

Wśród ogółu dzieci, gdy idzie o kłamstwo w domu, dla młodszych charakterystycznym motywem było łakomstwo: „Powiedziałam bonie, że ojciec chce rodzynków, tymczasem sama je zjadłam” (Dz. 8 lat; Baumgarten, 1927, s. 42). Owo łakomstwo w kolejnych latach życia prowadzi także do dokonywania drobnych kradzieży. „Wzięłam kopiejkę, kupiłam cukierków i powiedziałam, że mi sklepikarka je dała" (Dz. 13 lat; s. 43). Innym, jakby odwrotnym motywem kłamstwa było przymuszanie dzieci do jedzenia (s. 44). Stosunkowo często dzieci kłamały, kiedy nie wykonały nakazów rodziców. Ich kłamstwo, świadome i niekiedy skomplikowane, było podyktowane obawą przed karą: „Gdy miałem sześć lat, skłamałem, mówiąc, że się umyłem, nie robiąc tego wcale” (Chł. 11 lat; s. 44). Kłamstwa pojawiają się także po dokonaniu najrozmaitszych przewinień: "Stłukłam lalkę i z obawy powiedziałam, że sama spadła i stłukła się" (Dz. 15 lat; s. 45). Dzieci starsze, kiedy rozliczają się z drobnych zakupów, dokonują drobnych kradzieży i kłamią, aby je ukryć: „Skłamałem w domu, że kupiłem kajet, a kupiłem żołnierzy i mam ich w domu 52" (Chł. 11 lat; s. 46). Motyw utajania przed rodzicami w obawie przed karą (s. 46) pojawia się u dzieci starszych coraz częściej. Okazją ku temu bywają lektury zakazanych książek, zabronione zabawy, pójście do teatru lub kinematografu (jako przyczyna kłamstwa został wymieniony 60 razy!; s. 48), a nawet zwykłe spacery lub randki: „Kłamać muszę i nie żałuję tego, gdyż bez chłopców obejść się nie mogę, a rodzice nie pozwalają mi na to" (Dz. 16 lat; s. 49). Było też tak, że zupełnie „niewinne postępki” były przed rodzicami ukrywane i stawały się okazją dla kłamstwa, ponieważ między rodzicami i dziećmi brakowało szczerości i zaufania. Ale jest rzeczą ciekawą to, że „od 14 roku życia jednak daje się zauważyć systematyczne ukrywanie wszystkiego, co się tyczy wewnętrznego «ja»: dziewczyny lub chłopca” (s. 51). $\mathrm{W}$ tym schemacie można dobrze zrozumieć wypowiedź 15-letniego chłopca: „Kłamię w domu z powodu mych poglądów liberalnych” (s. 52).

\section{Kłamstwa w szkole}

Mniejsza różnorodność motywów kłamstwa występuje w sytuacjach szkolnych. Podkreślić należy to, że mamy na myśli nie liczbę kłamstw, ale ich zależność od szkolnych sytuacji. Zdaniem Franciszki Baumgarten (1927, s. 55-56) istnieją dwa rodzaje przyczyn, które powodują występowanie kłamstwa na terenie 
szkoły. Pierwszą z nich jest powszechnie znana obawa przed uzyskaniem „złego stopnia”, a drugą „osobowość” nauczyciela albo stosunki między uczniem i nauczycielem. Tę pierwszą możliwość ilustruje wypowiedź 16-letniego ucznia: „skłamałem, że zapomniałem kajetu, gdyż kara jest surowsza za nieodrobienie zadania, niż za zapomnienie kajetu" (s. 55). Ale owa sytuacja szkolna nie "gaśnie” wraz z momentem opuszczenia budynku szkoły. Zwraca na to uwage wypowiedź 15-letniego chłopca: ,jeśli się przyniesie do domu zły stopień, jest on materiałem gotowym do kłamstwa" (s. 56). Autorka uzupełnia tę wypowiedź, wskazując, że w tym przypadku motywem nie jest obawa przed karą, ale ambicja ucznia. Na to, że stosunki między uczniami oraz nauczycielami nie zawsze są przyjacielskie, wskazuje wypowiedź 12-letniej dziewczynki: „Naumyślnie skłamałam nauczycielce, bo ona jest zła" (s. 56). Natomiast 17-letnia dziewczyna chce także przez kłamstwo chronić swoją ambicję: „Kłamię chociażby dlatego, by nauczyciel nie odpowiedział szyderczym uśmiechem, bo o stopień wcale mi nie chodzi" (s. 57). Znanym motywem kłamstw związanych z nauką w szkole jest jeszcze „brak chęci do nauki” - z tej przyczyny: „podrabiam świadectwa i udaję chorobę" (Dz. 14 lat; s. 59).

W szkole, a dokładniej: na terenie szkoły istnieje jeszcze jeden rodzaj sytuacji, który Autorka określiła jako stosunki koleżeńskie. Również w tym terenie występuje szereg okazji, które albo zachęcają, albo wręcz „przymuszają” do kłamstwa. Rodzaj kłamstwa występujący w tych sytuacjach ma charakter szczególny: „Obawa kary jako motyw zanika, równość wieku, poziomu umysłowego, tożsamość interesów eliminuje trwogę" (Baumgarten, 1927, s. 60). Autorka wyróżnia dwa rodzaje kłamstw, które występują w stosunkach koleżeńskich i nadaje im określenia kłamstwa niekoleżeńskie i kłamstwa koleżeńskie (s. 61-68). Te pierwsze mają źródło w nieprzyjaznych uczuciach do szkolnych towarzyszy, drugie wynikają z uczuć przyjaznych. Wśród kłamstw niekoleżeńskich występowały takie, które towarzyszyły psotom, figlom i żartom wykonywanym dla zabawy własnej lub grupy, ale także z zamiarem sprawienia komuś bólu: „Skłamałam, żeby dokuczyć komuś” (Dz. 12 lat, s. 61), „Kłamałam, gdy chodziło, by znienawidzoną koleżankę oczernić" (Dz.12 lat, s. 63). Kłamstwa zaliczone do koleżeńskich uważa Baumgarten (s. 64) za „nader pocieszające dowody solidarności dzieci”. Dzisiaj, być może, należałoby je nazwać altruistycznymi? Oto kilka przykładów: "Często kłamię dla korzyści mego brata, który jest młodszy” (Chł. 16 lat, s. 64), "Skłamałem, że wcale w domu nie płakałem i wcale nie dostałem bicia” (Chł. 11 lat, s. 65), „Kłamałem dla wyrobienia sobie opinji lub podziwu” (Chł. 14 lat, s. 67).

Przedstawione przez Franciszkę Baumgarten opisy, grupowanie i wyjaśnienia motywów kłamstw nie prowadzą do wniosku, że kłamstwo jest zachowaniem powstającym wyłącznie według zasady przyczyna-skutek. Nietrudno zauważyć, że te same przyczyny nie wywołują ani zawsze, ani u tych samych osób tego samego skutku. Nie można zatem powiedzieć, że to zawsze określone sytuacje są lub bywają przyczyną kłamstwa. Formuła, którą przyjmuje Baumgarten, jest 
bardziej precyzyjna i nowoczesna. Autorka posługuje się określeniem motyw. Jakie znaczenia miał ten termin w roku 1914 w języku polskim, w roku 1917 w języku niemieckim i w języku polskim w roku 1927? Tych znaczeń istniało więcej. Oprócz najstarszego, energetycznego, wypada wziąć pod uwagę znaczenia bardziej współczesne względem pracy Baumgarten. Edelgard Daub (1996, s. 143, 144) wymienia serię czterech artykułów badaczki poświęconych psychoanalizie, opublikowanych w roku $1912 \mathrm{w}$ języku polskim, oraz jeden artykuł na ten sam temat napisany w języku niemieckim, opublikowany w roku 1920. Wydaje się jednak, że w tej pracy na temat kłamstwa nie posługiwała się pojęciem motywu w sensie psychoanalitycznym. Nie znajdujemy tutaj także jednoznacznej definicji motywu, ale w cytowanych przykładach są wyraźnie widoczne „myślowe struktury” ukazujące „celowość” kłamstwa, które bywa nader często zachowaniem wybranym świadomie dla osiągnięcia danego celu (lub uniknięcia zagrożenia). Można odnieść wrażenie, że Baumgarten dobiera stosowne przykłady z ankiet, aby pokazać kształtowanie się motywów zgodnie z regułami, które sformułował Wilhelm Wundt w pracach z lat 1863/1897 oraz 1907.

\section{STOSUNEK DO KEAMSTWA}

„Nie kłamię już więcej, ponieważ jestem skautem” - napisał 16-letni chłopiec (Baumgarten, 1927, s. 110). Wypowiedź ta wskazuje, że występowanie kłamstwa jest uzależnione od innych zmiennych regulujących zachowanie i postępowanie dziecka. Owe zmienne wpływają także na powstawanie motywów kłamstwa lub blokowanie go. W badaniach Baumgarten (1927, s. 71, 72): „159 [osób] odpowiedziało, że się wstydziło i żałowało swych kłamstw, 187 odrzekło, że się nie wstydziło i nie żałowało, 113 uwarunkowało swój żal i wstyd zależnością od okoliczności” oraz „realnością dla dziecka okazuje się ż y c i e z jego wymaganiami i wobec niego kłamstwo uważane jest, jako jego żelazna k o n i e c z n o ś ć". „Potwierdzeniem tego utylitaryzmu są zeznania dzieci, świadczące o żalu jedynie wtedy, jeśli kłamstwo nie przyniosło żadnej korzyści”.

Opierając się na wynikach swoich badań, Autorka formułuje opinię, że stosunek dzieci do kłamstwa cechuje wyraźny utylitaryzm, jest ono już w ich wieku wynikiem „sądu i rozmysłu”, a to znaczy, że kłamstwo jest popełniane z premedytacją i dla celów praktycznych. Na to, że ma ono charakter świadomy oraz instrumentalny, wskazują kolejne wypowiedzi dwóch chłopców w wieku 16 lat: „Jeżeli kłamstwo nie zostało wykryte, to go się nie wstydzę, i nie żałuję, bo kłamię świadomie i z rozmysłem” (Baumgarten, 1927, s. 73), „Nie wstydzę się, ale nie lubię kłamać przed nauczycielami, którzy mają zaufanie do uczniów" (s. 74). Wstyd, nawet gdyby ktoś był zdania, że jest uczuciem „staroświeckim”, jest kolejną interesującą strukturą myślową, w której „spotykają się" różne elementy, wymiary-punkty widzenia: twórcy i adresata kłamstwa, a także ono samo, tyle że już z legitymacją etycznej oceny. W ocenie dzieci oraz ich stosunku 
do kłamstwa wyraźna jest także obecność pewnych standardów dotyczących stosunków międzyludzkich. Dlatego 16-letni uczeń napisał (co już zauważyliśmy): „Nie wstydzę się, ale nie lubię kłamać przed nauczycielami, którzy mają zaufanie do uczniów" (s. jw.). A na stronie następnej znajdujemy wypowiedź uczennicy w tym samym wieku: „Nie żałuję kłamstwa, gdy popełniłam je w imię koleżeństwa". Ten ważny parametr modyfikujący i bardzo plastycznie ukazujący stosunek dzieci do kłamstwa akcentuje Autorka z całą wyrazistością: „kłamstwo samo przez się przychodzi dzieciom z trudnością wobec osób im sympatycznych lub przez nie kochanych. Po okłamaniu takich osób występuje też prawie zawsze wstyd" (s. 78).

Autorka wspomina, że po dokonaniu i zauważeniu kłamstwa część ankietowanych dzieci formułuje wnioski dotyczące przyszłości. Są one dwojakiego rodzaju. Jedne dotyczą postanowienia o niekłamaniu, drugie idą $\mathrm{w}$ kierunku przeciwnym zmierzają ku zwiększeniu efektywności kłamstwa. Stwierdzić zatem należy, że „inteligentniejsze dziecko, bardziej sprytne, bardziej orientujące się w otoczeniu, lepiej skłamie" (Baumgarten, 1927, s. 90). Uogólniając, możemy przyjąć sformułowanie Autorki: „W kłamstwach dzieci widzimy [...] obronę swego ja ${ }^{15}$, obronę swego indywidualnego odczuwania i sądu" (s. 92). Czynnikami, które prowokują lub nasilają występowanie kłamstwa u dzieci, są: ze strony rodziców zawyżone wymagania dotyczące wyników nauki szkolnej oraz rygorystyczne lub staroświeckie poglądy moralne, a ze strony nauczycieli - brak zaufania do ucznia.

Jest rzeczą zrozumiałą, że w dobrze jej znanej sytuacji społecznej i politycznej w ówczesnym Królestwie Polskim Franciszka Baumgarten dobrze oceniała wpływ wszelkich czynników środowiskowych także na osobliwość interesującego ją zjawiska. W tym kontekście szczególne znaczenie zyskuje jej uwaga na temat pewnej specyfiki „polskiego szkolnictwa” - tam i wówczas, tzn. na progu $\mathrm{XX}$ wieku pod carskim zaborem:

W szkołach polskich w Królestwie zdarzało się zazwyczaj, iż niektóre przedmioty, jak przyrodoznawstwo, psychologja etc. wykładane były w tajemnicy przed rosyjskimi naczelnikami okręgów naukowych. Dzieciom zakazane było wspominać o tem poza szkołą [...] Kłamstwo podobne wpływać musi nader ujemnie na dzieci, gdyż daje im jakby uprawnienie do kłamania. (1927, s. 105)

Ta uwaga wzbudza uznanie i respekt zarówno dla dociekliwości, jak również odwagi Autorki, ale także "polskiego nauczycielstwa”, które w nader skomplikowanej sytuacji zabiegało o dostarczenie kształcącej się młodzieży wiedzy dostosowanej do poziomu ówczesnej nauki.

15 Tutaj należy zauważyć, że - wprawdzie rozmaicie rozumiane - „pojęcie ja” było w europejskiej psychologii akademickiej obecne i używane, co najmniej od czasu Hermanna Ebbinghausa (1908/1910, s. 133-140). 
Swoje analizy i rozważania Franciszka Baumgarten kończy wyróżnieniem dwóch rodzajów kłamstwa. Są zatem takie, które nazywa r e a k t y w n y m i oraz te drugie, które określa jako a k t y w n e (1927, s. 123). Jest rzeczą oczywistą, że obydwa mogą zaistnieć tylko w warunkach społecznych, podczas kontaktów międzyludzkich. Kłamstwo reaktywne jest odpowiedzią na pewne pytanie; Autorka powiada, że owo pytanie musi być niedyskretne i zmusza zapytanego do ukrycia prawdy. Zatem za powstanie kłamstwa „winę tu ponosi nie odpowiadający, lecz pytający" (s. 123). Niebawem zobaczymy głębszy teoretyczny, ale także społeczny sens tego rozróżnienia. Drugi w tym podziale rodzaj kłamstwa to takie, „które dziecko popełnia samorzutnie [...] dla celów, które samo sobie postawiło" (s. 123). Sens tego rozróżnienia pozwala zauważyć, że pierwszy rodzaj kłamstwa pozostaje w związku z tym, co nazywamy odwagą. Baumgarten dodaje jednak, że w „zaciemnianiu prawdy” bierze udział także popęd samozachowawczy. I pisze: „wszędzie tam, gdzie są uciśnieni i ciemiężcy, gdzie są silni i słabi, tam też istnieje kłamstwo" (s. 111). Ale czy obok kłamstwa „obronnego" istnieje także kłamstwo „asertywne”? Dlatego warto i należy przypomnieć, że Baumgarten sformułowała swoje poglądy w roku... 1914 (!), w Kraju zniewolonym przez trzech zaborców. Ale czy można mieć nadzieję, że jej ustalenia i poglądy odnoszą się tylko do przeszłości? W każdym razie pod koniec lektury tej książki także jej czytelnik nie chce się zgodzić z postulatem ówczesnych pedagogów, że „kłamstwo jest występkiem” (s. 109).

\section{ZAKOŃCZENIE}

Tymczasem skończył się okres zniewolenia w Polsce i kilku innych krajach. U najbliższych sąsiadów upadek i rozpad Cesarstwa stał się przyczyną depresji i poszukiwań. Nie wiemy, czy ponowne wydanie w Lipsku w roku 1926 książki Franciszki Baumgarten Die Lüge bei Kindern und Jugendlichen miało wnieść coś nowego do toczących się tam dyskusji? Okazało się jednak, że tematyka książki nie tylko czytelników zainteresowała, lecz także skłoniła niektórych nawet do korespondencji z Autorką książki i dopytywania się, jak wyglądały jej własne kłamstwa z okresu dzieciństwa. Otrzymane zapytania Franciszka Baumgarten potraktowała poważnie, a jej odpowiedź ukazała się drukiem w roku 1930 w czasopiśmie „Zeitschrift für Pädagogische Psychologie” w artykule pt. Meine Kinderlügen (Moje kłamstwa dziecięce). Owszem, było ich kilka. Spośród trzech opisanych ostatnie wykracza poza ramy tego, co nazywamy kłamstwem dziecięcym. Franciszka ma wówczas 15 lat ${ }^{16}$, rzecz dzieje się w Łodzi, pod zaborem rosyjskim, zaraz na początku XX wieku. Franciszka jest

16 Określenie wieku Franciszki Baumgarten, szczególnie w okresie uczęszczania do szkoły, jest utrudnione, albowiem jej biografowie podają różne daty urodzenia: 1883 (Daub), 1888 (Stachowski), 1889 (Internet). 
uczennicą rosyjskiego gimnazjum, w którym obowiązuje zakaz posługiwania się językiem polskim. Na co dzień przypomina o tym specjalne ogłoszenie. Wśród uczennic klasy, do której uczęszcza Franciszka, znaczną część stanowią te, których dziadkowie uczestniczyli w powstaniu styczniowym, a po jego upadku zostali skazani na śmierć albo wypędzeni na Syberię. W tym samym gimnazjum uczą się dziewczęta narodowości polskiej, rosyjskiej, niemieckiej oraz z rodzin żydowskich. Patriotyzmu Polek nikt nie kwestionuje, ba, jest wręcz respektowany. Pewnego dnia owo ogłoszenie spadło na ziemię i zostało podeptane. Fakt został zauważony, a władze szkolne natychmiast wszczęły dochodzenie i poszukiwanie sprawczyni. Baumgarten komentuje zerwanie ogłoszenia jako akt patriotyzmu dziewcząt, podkreśla aplauz, z jakim spotkał się sam czyn. I zaraz odkrywa nowy rodzaj kłamstwa: kłamstwo kolektywne. Stanowi ono ochronę sprawczyni. Ale jej czyn - w grupie nieformalnej - zyskał już uznanie wszystkich uczennic. Zatem pomimo bardzo surowych gróźb nikt się nie przyznaje, nikt też nie ujawnia, co jest mu w tej sprawie wiadomo. Kłamstwo przestaje być kłamstwem!? Jego miejsce zajmuje s o li d a r n ość . Solidarność przeciw ograniczaniu wolności, solidarność przeciw zniewoleniu. Owo kolektywne kłamstwo przez towarzyszące mu poczucie solidarności utraciło swój pierwotny etyczny charakter i stało się pięknym przeżyciem. Bo i tutaj błędnym było pytanie, a nie odpowiedź ${ }^{17}$.

Jeżeli na ową wczesną pracę Franciszki Baumgarten spojrzymy w tej właśnie perspektywie, nadamy jej jeszcze większe znaczenie. Stanie się ona swoistym wprowadzeniem w problematykę badania rzeczywistych, „tutejszych” stosunków międzyludzkich, bez redukowania ich do obiegowych kategorii moralnych albo fikcyjnych obrazów z innego kontynentu. Właśnie do takich problemów Autorka książki w swojej późniejszej, w pełni dojrzałej twórczości będzie wielokrotnie powracała i rozpatrywała je w coraz to innej, aktualnej perspektywie.

\section{Bibliografia}

Ash, M.G. (1995). Gestalt psychology in German culture, 1890-1967. Cambridge: Cambridge University Press.

Baumgarten, F. (1917). Die Lüge bei Kindern und Jugendlichen. Eine Umfrage in den polnischen Schulen von Lodz. Leipzig: Verlag von Johann Ambrosius Barth. (Wydanie polskie: Baumgarten, F. (1927). Kłamstwo dzieci i młodzieży (Na podstawie ankiety $w$ szkołach łódzkich). Warszawa: Nasza Księgarnia.

Baumgarten, F. (1930). Meine Kinderlügen. Zeitschrift für Pädagogische Psychologie, 31(1), 53-57.

Baumgarten, F. (1944). Demokratie und Charakter. Zürich: Rascher Verlag.

17 „Denn in solchen Fällen hat nicht der Lügende, sondern der Belogene schuld“ (Baumgarten, 1930, s. 57). 
Bühler, Ch. (1962). Die Psychologie im Leben unserer Zeit. München/Zürich: Verlag Droemer Knaur.

Claparède, É. (1918). Psychologia dziecka i pedagogika eksperymentalna (tł. Franciszka Baumgarten; red. nauk. Florian Znaniecki). Warszawa: Wende. Daub, E. (1996). Franziska Baumgarten: Eine Frau zwischen akademischer und praktischer Psychologie. Frankfurt a./M.: Peter Lang Europäischer Verlag der Wissenschaften.

Daub, E. (2015). Franziska Baumgarten-Tramer: o naukowość psychologii praktycznej. W: S. Volkmann-Raue, H.E. Lück (red.), Najwybitniejsze kobiety w psychologii XX wieku (s. 269-282). Sopot: GWP. (Org.: 2011) S. VolkmannRaue, H.E. Lück (red.). (2011). Bedeutende Psychologinnen des 20. Jahrhunderts (2. Aufl.), Wiesbaden: Springer Verlag für Sozialwissenschaften.

Ebbinghaus, H. (1908/1910). Abriss der Psychologie. Leipzig: Verlag von Veit \& Comp.

Giger, M. (2010). Franziska Baumgartens Wunderkinder. Swiss Gifted, 3(2), 67-75. Heinrich, W. (1988). U podstaw psychologii i inne pisma. Warszawa: Państwowe Wydawnictwo Naukowe.

Heymans, G. (1910). Die Psychologie der Frauen. Heidelberg: C. Winter's Universitätsbuchhandlung.

Heymans, G., Wiersma, E. (1906). Beiträge zur speziellen Psychologie auf Grund einer Massenuntersuchung. W: H. Ebbinghaus (red.), Zeitschrift für Psychologie, 42, 81-301. Leipzig: Verlag von J.A. Barth.

Krueger, F., Spearman, C. (1906). Korrelation zwischen verschiedenen geistigen Leistungsfähigkeiten. Zeitschrift für Psychologie, 44, 50-114.

Maercker, A. (2007). Geschichte des Psychologischen Instituts der Universität Zürich. Pobrane z http://www.psychologie.uzh.ch/de/institut/informationen/ geschichte/geschichte-bis-2006.html

Malewska, H.E., Muszyński, H. (1962). Kłamstwo dzieci. Warszawa: PZWS.

Hildebrandt H., Scheerer H. (red.). (1990). Hugo Münsterberg. Frühe Schriften zur Psychologie. Berlin, Heidelberg: Springer-Verlag.

Panczyk, P., Zeidler, W. (2011). Jak powstawała polska naukowa terminologia psychologiczna: koncepcja abstrakcji Kazimierza Twardowskiego. W: W. Zeidler, H. Lück (red.), Psychologia europejska w okresie międzywojennym (s. 245-269). Warszawa: VIZJA PRESS\&IT.

Richebächer, S. (2010). Franziska Baumgarten (1883-1970). Polnisch-schweizerische Arbeitspsychologin, Berner Universitätslehrerin, Pazifistin. Punktum „Arbeit“, 4, 5-7. Pobrane $\mathrm{z}$ http://www.richebaecher.com/pdf/Punktum_Baumgarten.pdf Roback, A.A. (1952). A history of American Psychology. Nowy Jork: Library Publishers.

Rudmin, F. (2006). Franziska Baumgarten (1883-1970): Early Female, Jewish, Peace Psychologist. Pobrane z http://www.humiliationstudies.org/documents/ RudminBioBaumgarten14Nov.pdf 
Rzepa, T., Dobroczyński, B. (2009). Historia polskiej myśli psychologicznej. Warszawa: Wydawnictwo Naukowe PWN.

Stachowski, R. (1992). Baumgarten-Tramer Franciszka. W: E. Kosnarewicz, T. Rzepa, R. Stachowski (red.), Słownik Psychologów Polskich (s. 26). Poznań: Instytut Psychologii UAM.

Stachowski, R. (2000). Historia współczesnej myśli psychologicznej. Warszawa: Wydawnictwo Naukowe SCHOLAR.

Stachowski, R. (2011). Pierwszy polski kwestionariusz psychologiczny. W: W. Zeidler (red.), Kwestionariusze w psychologii. Postępy, zastosowania, problemy (s. 139-157). Warszawa: VIZJA PRESS\&IT.

Stern, W. (1994; reprint wydania z roku 1911). Die Differentielle Psychologie in ihren methodischen Grundlagen. Berno, Getynga, Toronto, Seattle: Verlag Hans Huber.

Tatarkiewicz, W. (2001; wyd. XV). Historia Filozofii. Tom 3. Warszawa: Wydawnictwo Naukowe PWN.

Woodworth, R.S. (1919). Examination of emotional fitness for war. Psychological Bulletin, 6, 59-60.

Wundt, W. (1863/1897). Vorlesungen über die Menschen- und Thierseele. Hamburg, Lipsk: Verlag von Leopold Voss.

Wundt, W. (1907; wyd. VIII). Grundriss der Psychologie. Lipsk: Verlag von Wilhelm Engelmann.

Wundt, W. (1908). Logik der Geisteswissenschaften. Stuttgart: Verlag von Ferdinand Enke.

Wundt, W. (1916). Zur Lage. Polnische Blätter, 5, 99-101.

Zeidler, W. (2003). O różnych sposobach uprawiania historii psychologii. Edukacja Humanistyczna, 1-2, 49-63.

Zeidler, W. (2008). Początki polsko-niemieckich kontaktów w zakresie psychologii. W: H. Lück (red.), Historia Psychologii. Orientacje, szkoły, kierunki rozwoju (s. 225-245). Warszawa: VIZJA PRESS\&IT.

Zeidler, W. (2011a). Kwestionariusze w psychologii: kierunki rozwoju i pierwsze filiacje teoretyczne. W: W. Zeidler (red.), Kwestionariusze w Psychologii. Postępy, zastosowania, problemy (s. 15-78). Warszawa: VIZJA PRESS\&IT.

Zeidler, W. (2011b). Kwestionariusze w psychologii: pionierskie zastosowania w badaniach naukowych. W: W. Zeidler (red.), Kwestionariusze w Psychologii. Postępy, zastosowania, problemy (s. 79-138). Warszawa: VIZJA PRESS\&IT. Zeidler, W. (2012). Lück jako historyk psychologii. Studia Psychologica, 12(1), 125-146.

Zeidler, W., Lück, H. (2014). Zapomniany dokument: „Księga Pamiątkowa” Pierwszej Ogólnopolskiej Konferencji Psychotechnicznej. Warszawa, styczeń 1930. Studia Psychologica, 13(2), 77-94. 